\section{Factors Affecting Germination, Emergence and Establishment of Sand Bluestem ${ }^{1}$}

\author{
J. STUBBENDIECK AND WAYNE G. MCCULLY \\ Assistant Range Scientist and Professor, Department of Range \\ Science, Texas AઐM University, College Station.
}

\section{Highlight}

Response of sand bluestem seed units (florets) to three rates of cotton-bur mulch and treatment with an organic mercury pathogenicide was measured by germination, emergence and establishment. All rates of cotton-bur mulch improved soil moisture conditions, but heavier rates formed a physical barrier to the emergence of grass seedlings. More than three times as many plants became established from florets treated with a pathogenicide than from untreated florets.

Sand bluestem (Andropogon hallii Hack.) is an important range grass on sandy lands throughout the Great Plains and the Southern High Plains. It is a tall, palatable and nutritious warm-season grass used for seeding rangeland and abandoned cropland.

An environment favorable for seed germination and seedling growth is a prime requisite for successful plant establishment. A recent survey (Great Plains Agricultural Council, 1966) showed: (1) seeding success diminishes from north to south within the Great Plains, (2) sands are one of the most difficult soils on which to establish grass, and (3) more intensive practices, including a litter cover or mulch, give better stands. The importance of soil moisture and of moisture-conserving practices is well established (Griffith, 1910;

\footnotetext{
${ }^{1}$ Published with the approval of the Director of the Texas Agricultural Experiment Station as TA-9395. Received September 13, 1971.
}

Thornber, 1910; Wooton, 1916; Glendening, 1941; Doneen and MacGillivary, 1943; Ayers, 1952; Helmrich and Pfeiffer, 1954; McGinnies, 1960; and Bement, et al., 1961).

Manipulating the habitat to improve grass seed germination and seedling emergence also encourages pathogen development. High grass seedling mortality due to pathogens has been observed under good moisture conditions (Shultz and Biswell, 1953). Pathogen injury also has been associated with cold, wet weather following planting (Tatum and Zuber, 1943; Laude, 1956). Preemergence infection was most severe under habitat conditions more favorable to the pathogen than the host (Leach, 1947). Disinfecting with a fungicide destroyed seedborne organisms and may have established a barrier immediately surrounding the seed which protected it from attack by soil-borne pathogens (Jones, 1939; Haskell, 1949).
Five accessions of sand bluestem were used; they included Woodward and Elida varieties and G-1742,2 G-1773 and G-1805 collected in western Texas. Florets were planted in Amarillo sandy clay loam at the U.S. Big Spring Field Station at Big Spring, Texas. $^{3}$ The surface soil is weakly alkalinc, wcakly granular to structureless, varies from 7 to 10 inches thick and forms a thin crust on drying. Amarillo sandy clay loam is one of the major soils of the Texas High Plains (Burnett, Oakes and Godfrey, 1962). A splitplot design was used with sand bluestem varieties or accessions as the main plot; subplots were seed treatments and the sub-subplots were mulch treatments. Thiram (tetramethylthiuramdisulfide) dust was used as the pathogenicide. Cotton-burs were used as a surface mulch at $0,2.5$, and 5.0 tons per acre. The treatments were replicated four times each year.

Each plot, seeded to sand bluestem florets in late April, 1969 and in early May, 1970, consisted of six rows, 40 inches apart and $20 \mathrm{ft}$ long. Florets were planted with a hand planter to a depth of $1 / 2$ inch in a clean seedbed at the rate of 12 pure

${ }^{2}$ Plant materials collected for potential drought resistance in a cooperative program with New Crops Branch, Crops Research Division, Agricultural Research Service.

${ }^{3}$ The U.S. Big Spring Field Station is a cooperative research facility maintained by the Soil and Water Conservation Division of Agricultural Research Service and the Texas Agricultural Experiment Station. 
Table 1. Effect of mulch (T/acre) on the germination (\%), emergence (\%), and establishment (\%), of sand bluestem.

\begin{tabular}{|c|c|c|c|c|c|c|}
\hline \multirow[b]{2}{*}{ Measurement } & \multicolumn{3}{|c|}{$1969^{1}$} & \multicolumn{3}{|c|}{$1970^{2}$} \\
\hline & $0.0 \mathrm{~T} / \mathrm{acre}$ & $2.5 \mathrm{~T} /$ acre & $5.0 \mathrm{~T} / \mathrm{acre}$ & $0.0 \mathrm{~T} / \mathrm{acre}$ & $2.5 \mathrm{~T} / \mathrm{acre}$ & $5.0 \mathrm{~T} / \mathrm{acre}$ \\
\hline Total established & $17.5 \mathrm{~b}$ & $22.2 \mathrm{a}$ & $18.5 \mathrm{ab}$ & $12.0 \mathrm{y}$ & $16.8 \mathrm{x}$ & $9.4 \mathrm{y}$ \\
\hline Lost to pathogens & $0.5 \mathrm{a}$ & $2.0 \mathrm{a}$ & $2.7 \mathrm{a}$ & $1.0 \mathrm{x}$ & $2.5 \times$ & $3.4 \mathrm{x}$ \\
\hline Lost to soil drying & $16.2 \mathrm{a}$ & $12.9 \mathrm{a}$ & $4.0 \mathrm{~b}$ & $15.9 \mathrm{x}$ & $9.4 \mathrm{y}$ & $3.0 \mathrm{z}$ \\
\hline Lost to wind-blown sand damage & $4.5 \mathrm{a}$ & $3.7 \mathrm{a}$ & $3.2 \mathrm{a}$ & $15.9 \times$ & $12.2 \times$ & $13.0 \mathrm{x}$ \\
\hline Lost to insect and rodent damage & $5.5 \mathrm{a}$ & $6.1 \mathrm{a}$ & $5.5 \mathrm{a}$ & $9.0 \mathrm{x}$ & $9.5 \times$ & $9.5 \times$ \\
\hline Total emerged & 44.2 a & $46.9 \mathrm{a}$ & $33.9 \mathrm{~b}$ & $53.8 \times$ & $50.4 \mathrm{x}$ & $38.3 \mathrm{y}$ \\
\hline Lost to pathogens & $0.8 \mathrm{a}$ & $2.3 \mathrm{a}$ & $3.7 \mathrm{a}$ & $1.2 \times$ & $2.7 \times$ & $4.0 \times$ \\
\hline Lost to soil drying & $34.7 \mathrm{a}$ & $17.4 \mathrm{~b}$ & $5.5 \mathrm{c}$ & $35.0 \times$ & $17.3 \mathrm{y}$ & $3.7 \mathrm{z}$ \\
\hline Unemerged due to mulch barrier & $0.0 \mathrm{c}$ & $13.0 \mathrm{~b}$ & $31.2 \mathrm{a}$ & $0.0 \mathrm{z}$ & $13.4 \mathrm{y}$ & $31.7 \mathrm{x}$ \\
\hline Lost to insect and rodent damage & $1.7 \mathrm{a}$ & $2.7 \mathrm{a}$ & $2.9 \mathrm{a}$ & $1.7 \times$ & $1.8 \mathrm{x}$ & $2.3 \times$ \\
\hline Total germinated & $81.4 \mathrm{a}$ & $82.3 \mathrm{a}$ & $77.2 \mathrm{~b}$ & $91.7 \mathrm{x}$ & $85.6 \mathrm{y}$ & $80.0 \mathrm{z}$ \\
\hline Lost to pathogens & $15.2 \mathrm{~b}$ & $15.3 \mathrm{~b}$ & 20.1 a & $7.0 \mathrm{z}$ & $14.0 \mathrm{y}$ & $20.0 \times$ \\
\hline Ungerminated caryopses & $3.4 \mathrm{a}$ & $2.4 \mathrm{a}$ & $2.7 \mathrm{a}$ & $1.3 \times$ & $0.4 \mathrm{x}$ & $0.0 \mathrm{x}$ \\
\hline Total seed units & 100.0 & 100.0 & 100.0 & 100.0 & 100.0 & 100.0 \\
\hline
\end{tabular}

${ }_{1}^{1} 1969$ mean values, for comparison between different mulch rates, followed by different letters (a, b and/or c) are significantly different at the $5 \%$ level of probability.

${ }^{2} 1970$ mean values, for comparison between different mulch rates, followed by different letters (x, y and/or $z$ ) are significantly different at the $5 \%$ level of probability.

live seeds per linear foot. Ten, 1ounce paper cups were used as containers for individual grass florets planted in the center row of each sub-subplot. The bottom of each cup was cut to facilitate drainage and root growth. The location of each cup was marked with a 2-inch strip of plastic attached with a wire staple.

Seedling emergence, rate of growth and seedling survival were recorded weekly for nine weeks after planting. Cups with no seedlings after nine weeks were recovered, and the seed units were placed in a laboratory germinator at $85 \mathrm{~F}$ to determine germination. Seedlings which failed to emerge were examined to ascertain the reason for failure.

Moisture in the surface 3 inches of soil was determined gravimetrically at 3-day intervals in 1969 and weekly intervals in 1970 . Temperature of the soil surface was determined under various atmospheric conditions using a thermistor probe. Rainfall and other weather data were recorded at a nearby official weather station. Three sprinkler irrigations were applied in 1970 to avoid moisture stress during a prolonged dry period.

\section{Results and Discussion}

Transformation of a planted grass seed into an established plant is a sequence of developmental stages beginning with seed germination. A surface mulch favors grass establishment from seeding but the advantage gained is largely offset by increased pathogen activity under mulch (Table 1).

Pathogen activity accountcd for the loss of approximately 25 to $35 \%$ of the florets planted but treatment with thiram effectively reduced pathogen activity (Table 2). A tendency was observed for scedlings grown under heavy rates of mulch to be susceptible to pathogen activity but the numbers involved were not great.

Following germination, physical, rather than biological, factors of the habitat determined seedling survival. A tendency existed for improved germination under mulch but the numbers were small.

Moisture content of the soil was enhanced by a surface mulch but cotton-burs served as a physical barrier to the emergence of germinated grass seedlings (Table 1). Approximately $50 \%$ of the germinated seed emerged as seedlings (Tables 1 and 2).
Temperatures of the surface 0.5 inch of soil varied with weather conditions, moisture content of the soils and time of day. Maximum temperatures recorded were 114, 106 and $94 \mathrm{~F}$ under mulch rates of $0,2.5$ and $5.0 \mathrm{~T} /$ acre, respectively. Minimum temperatures were 87 , 85 and $81 \mathrm{~F}$. 'Temperatures averaged 7 to $14 \mathrm{~F}$ lower under 2.5 and 5.0 $\mathrm{T}$ /acre than where no mulch was applied.

The apparent increase in loss of emerging seedlings from florets treated with thiram (Table 2) was a function of the greater number of seeds germinating in each case. On the basis of number of seeds germinated rather than planted, the percentage loss from desiccation was approximately the same for treated and untreated seed.

Neither mulching nor thiram treatments affected the number of plants lost from causes such as insects, rodents or soil blowing (Tables 1 and 2). A larger percentage of plants was lost in 1970 than in 1969 due to soil blowing. More days with blowing sand occurred in 1970. I osses due to blowing sand were due largely to smothering by the blown material, particularly on the mulch treatments. 
Table 2. Effect of pathogenicide treatment on the germination (\%), emergence $(\%)$, and establishment (\%) of sand bluestem for two separate years.

\begin{tabular}{|c|c|c|c|c|}
\hline \multirow[b]{2}{*}{ Measurement } & \multicolumn{2}{|c|}{$1969^{1}$} & \multicolumn{2}{|c|}{$1970^{2}$} \\
\hline & Treated & Untreated & Treated & Untreated \\
\hline Total established & $31.4 \mathrm{a}$ & $8.9 \mathrm{~b}$ & $19.5 \mathrm{x}$ & $6.4 \mathrm{y}$ \\
\hline Lost to pathogens & $1.1 \mathrm{a}$ & $2.3 \mathrm{a}$ & $1.3 \mathrm{x}$ & $3.2 \times$ \\
\hline Lost to soil drying & $11.2 \mathrm{a}$ & $10.8 \mathrm{a}$ & $9.4 \mathrm{x}$ & $9.4 \times$ \\
\hline $\begin{array}{l}\text { Lost to wind-blown sand } \\
\text { damage } \\
\text { Lost to insect and rodent }\end{array}$ & 4.2 a & $4.0 \mathrm{a}$ & $14.0 \mathrm{x}$ & $13.3 \mathrm{x}$ \\
\hline damage & $6.4 \mathrm{a}$ & $5.0 \mathrm{a}$ & $8.8 \mathrm{x}$ & $9.9 \mathrm{x}$ \\
\hline Total emerged & $54.3 \mathrm{a}$ & $31.0 \mathrm{~b}$ & $53.0 \mathrm{x}$ & $42.2 \mathrm{y}$ \\
\hline Lost to pathogens & $1.6 \mathrm{a}$ & $2.9 \mathrm{a}$ & $2.0 \mathrm{x}$ & $3.2 \mathrm{x}$ \\
\hline Lost to soil drying & $21.3 \mathrm{a}$ & $15.7 \mathrm{~b}$ & $21.8 \times$ & $15.5 \mathrm{y}$ \\
\hline Unemerged due to mulch & & & & \\
\hline barrier & $14.9 \mathrm{a}$ & $14.2 \mathrm{a}$ & $16.4 \mathrm{x}$ & $13.6 \times$ \\
\hline $\begin{array}{l}\text { Lost to insect and rodent } \\
\text { damage }\end{array}$ & $2.4 \mathrm{a}$ & $2.4 \mathrm{a}$ & $2.1 \mathrm{x}$ & $1.8 \mathrm{x}$ \\
\hline Total germinated & $94.5 \mathrm{a}$ & $66.2 \mathrm{~b}$ & $95.3 \mathrm{x}$ & $76.3 \mathrm{y}$ \\
\hline Lost to pathogens & $2.8 \mathrm{~b}$ & 30.9 a & $4.0 \mathrm{y}$ & $23.3 \times$ \\
\hline Ungerminated caryopses & $2.7 \mathrm{a}$ & $2.9 \mathrm{a}$ & $0.7 \times$ & $0.4 \mathrm{x}$ \\
\hline Total seed units & 100.0 & 100.0 & 100.0 & 100.0 \\
\hline
\end{tabular}

The rate of growth, expressed in terms of extended leaf height, of Elida sand bluestem was significantly larger than the other variety and the three accessions. This was the only significant difference between the varietics or accessions throughout the duration of the experiment.

\section{Summary and Conclusions}

A planted seed that germinates and grows into an established plant is influenced by a number of habitat factors which vary with stage of plant development. A surface mulch conserves moisture in the upper layer of soil. This moist habitat favors the development of pathogens which attack germinating seed. However, loss of germinating seeds to pathogens was overcome by seed treatment with a pathogenicide. Seedlings were nearly immune to disease organisms but they were susceptible to desiccation.
More than $50 \%$ of the seedlings on the unmulched plots did not survive soil drying. However, cottonburs, a waste material from the ginning process, interfered with grass seedling emergence.

Results from these studics indicate that moisture conservation is important to the success of range plant seedlings. However, these advantages may be offset by pathogen activity on gcrminating seeds if not pretreated with a pathogenicide. Furthermore, emergence may be dependent on the type of mulch applied.

\section{Literature Cited}

Ayers, A. D. 1952. Seed germination as affected by soil moisture and salinity. Agron. J. 44:82-83.

Bement, R. F., D. F. Hervey, A. G. Everson, and L. D. Hylton, JR. 1961. Use of asphalt-emulsion mulches to hasten grass seedling establishment. J. Range Manage. 14: 102-109.
Burnett, E., H. OAKes, and C. L. GodFREY. 1962. Soils of the Big Spring Field Station. Texas Agr. Exp. Sta. Misc. Pub. 559.

Doneen, L. D., and J. H. MacGillivarY. 1943. Germination (emergence) of vegetable seeds as affected by differential soil moisture conditions. Plant Phy. 18:524-529.

FulKerson, R. S. 1953. A preliminary study of the effect of some fungicides on establishment of forage seedlings. Canadian J. Agr. Sci. 33:30-40.

Glendening, G. E. 1941. Development of seedlings of Heteropogon contortus as related to soil moisture and competition. Bot. Gaz. 102:684698.

Great Plains Agricultural Council. 1966. A stand survey of grass plantings in the Great Plains. Great Plains Council Rept. No. 23.

Griffith, D. 1910. A protected stock range in Arizona. U.S. Dep. $\Lambda$ gr. Bur. Plant Indust. Bull. 177.

Haskell, Royal J. 1949. The role of alkyl mercury as a fungicide. Agr. Chem. 4:30-32.

Helmrich, R. H., and R. P. Pfeifer. 1954. Differential varietal responses of winter wheat germination and early growth to controlled limited moisture conditions. Agron. J. 46: $560-562$.

Jones, Fred R. 1939. Four fungus parasites of sweet clover infecting seeds. Phytopathology 29:912-913.

LAude, H. M. 1956. Seedling emergence of grasses as affected by low temperature. Agron. J. 48:558-560.

LEACH, L. D. 1947. Growth rates of host and pathogen as factors determining the severity of pre-emergence damping-off. J. Agr. Res. 75:161179.

McGinnies, W. J. 1960. Effects of moisture stress and temperature on germination of six range grasses. Agron. J. 52:159-162.

Shultz, A. M., AND H. H. Biswell. 1953. Reseeding burned rangeland. Calif. Agr. 7:3-4.

Tatum, L. A., ANd M. S. Zuber. 1943. Germination of maize under adverse conditions. J. Amer. Soc. Agron. 35: 48-59.

Thornber, J. J. 1910. The grazing ranges of Arizona. Arizona Agr. Expt. Sta. Bull. 65.

Wooton, E. O. 1916. Carrying capacity of grazing ranges in Southern Arizona. U.S. Dep. Agr. Bull. 367. 